\title{
Physical and biogeochemical limits to internal nutrient loading of meromictic Lake Kivu
}

\author{
Natacha Pasche, a,b, ${ }^{*}$ Christian Dinkel, ${ }^{a}$ Beat Müller,a,b Martin Schmid, ${ }^{a}$ Alfred Wüest, a,b and \\ Bernhard Wehrlia,b \\ a Eawag, Swiss Federal Institute of Aquatic Science and Technology, Surface Waters Research and Management, Kastanienbaum, \\ Switzerland \\ ${ }^{\text {b }}$ Swiss Federal Institute of Technology, Institute of Biogeochemistry and Pollutant Dynamics, Zürich, Switzerland
}

\begin{abstract}
Lake Kivu is one of the large African Rift lakes situated between the Democratic Republic of the Congo and Rwanda. In its permanently stratified hypolimnion, unusually high methane concentrations have increased further in recent decades. Because methanogenesis is, in part, dependent on supply of organic material from the photic zone, it is necessary to quantify upward nutrient fluxes from the saline, nutrient rich deep waters. These upward fluxes are mainly driven by advection caused by subaquatic springs. Biogenic calcite precipitation drives surface water depletion and deep water enrichment of $\mathrm{Ca}^{2+}, \mathrm{Sr}^{2+}$, and $\mathrm{Ba}^{2+}$. Methane is mainly oxidized aerobically at the redox interface at $60 \mathrm{~m}$, with a small contribution of anaerobic methane oxidation. A subaquatic spring that sustains the major chemocline at $250 \mathrm{~m}$ depth was depleted of $\mathrm{N}, \mathrm{P}$, and $\mathrm{CH}_{4}$, and concentrations of major ions were slightly lower than in the lake water of the same depth. Enrichment of the deep waters with nutrients and $\mathrm{CH}_{4}$ are driven by mineralization of settling organic material, whereas $\mathrm{SiO}_{2}$ is influenced by uptake and mineralization of diatoms and inputs through subaquatic springs. Dissolved inorganic phosphorus and $\mathrm{Si}$ fluxes supplied by internal loading through upwelling were found to be lower than the estimations for Lakes Malawi and Tanganyika. In contrast, N flux was within the lower range for Lake Malawi, whereas it was assumed to be totally lost by denitrification in Lake Tanganyika. In Lake Kivu, nutrient uptake by primary production is three times higher than nutrient upward fluxes.
\end{abstract}

The deep tropical lakes of the African Rift Valley are characterized by a specific limnology with permanent stratification (Kilham and Kilham 1990) accompanied by an export of nutrients from the mixed surface layer to the deep waters via settling of particulate organic material. The resulting large reservoirs of dissolved nutrients in the deep water sustain internal loading to the photic zone via upward fluxes, which are crucial for nutrient availability and phytoplankton growth (Hecky et al. 1996). Recent studies showed that primary production in Lake Malawi and Lake Tanganyika is driven by the import of nutrients from the deep waters via turbulent diffusion and upwelling (Bootsma and Hecky 1993; Hamblin et al. 2003). This upward transfer fuels dark microbial production at the oxycline, where large amounts of nutrients can be consumed in biogeochemical processes such as methanothrophy (Joye et al. 1999; Camacho et al. 2001; Hadas and Pinkas 2001) and coupled nitrification and denitrification (Hecky et al. 1996). These processes can be so intense that they limit the upward fluxes of nutrients otherwise available for phytoplankton growth. Quantifying upward nutrient fluxes across the redox interface to the epilimnion is therefore essential to determine nutrient cycling and primary production of these tropical lakes.

Lake Kivu is one of those large East African rift lakes. It is meromictic, and the oligotrophic (Sarmento et al. 2006) epilimnion is permanently separated from the anoxic nutrient-rich deep waters. The water column is characterized by a seasonally variable thermocline in the depth range of $4070 \mathrm{~m}$ and two stable chemoclines from 67 to $130 \mathrm{~m}$

\footnotetext{
* Corresponding author: natacha.pasche@eawag.ch
}

and from 255 to $261 \mathrm{~m}$. The extremely slow upward transport is dominated by upward advection caused by subaquatic springs; turbulent diffusion is exceptionally weak. This particular physical setting results in a residence time of 800 to $1000 \mathrm{yr}$ for the water below the major chemocline (255 $261 \mathrm{~m}$; Schmid et al. 2005) and an enormous accumulation of dissolved gases and nutrients in the deep water (Schmid et al. 2004). With a methane reservoir of $60 \mathrm{~km}^{3}$ at standard conditions for temperature and pressure (gas volume at $0^{\circ} \mathrm{C}$ and $1.013 \times 10^{5} \mathrm{~Pa}$ ) and concentrations up to $18 \mathrm{mmol} \mathrm{L} 1$, Lake Kivu is unique worldwide. Recent measurements indicate that methane concentrations increased by $15 \%$ in the last $30 \mathrm{yr}$ (Schmid et al. 2005). Methanogenesis, which contributes to methane production, is dependent on sedimenting organic matter arising from primary production. Quantifying internal and external loading of nutrients is essential to determine nutrient availability for phytoplankton growth. Whereas the focus of this paper is on internal loading, the external nutrient inputs are assessed in a companion study (Muvundja et al. in press).

The aim of this publication is to quantify key processes occurring in the water column, including subaquatic inputs, the calcite cycle, nutrient turnover, and methane oxidation. We are addressing the following questions: (1) What physical and biogeochemical processes are influencing the concentration profiles of nutrients and major ions in the water column of Lake Kivu? (2) What is the composition of the deep water inflows? (3) How large is the internal loading via upward fluxes of nutrients?

Concentration profiles of the conservative elements $\mathrm{Na}^{+}$ and $\mathrm{Cl}$ were used to quantify vertical mixing and 


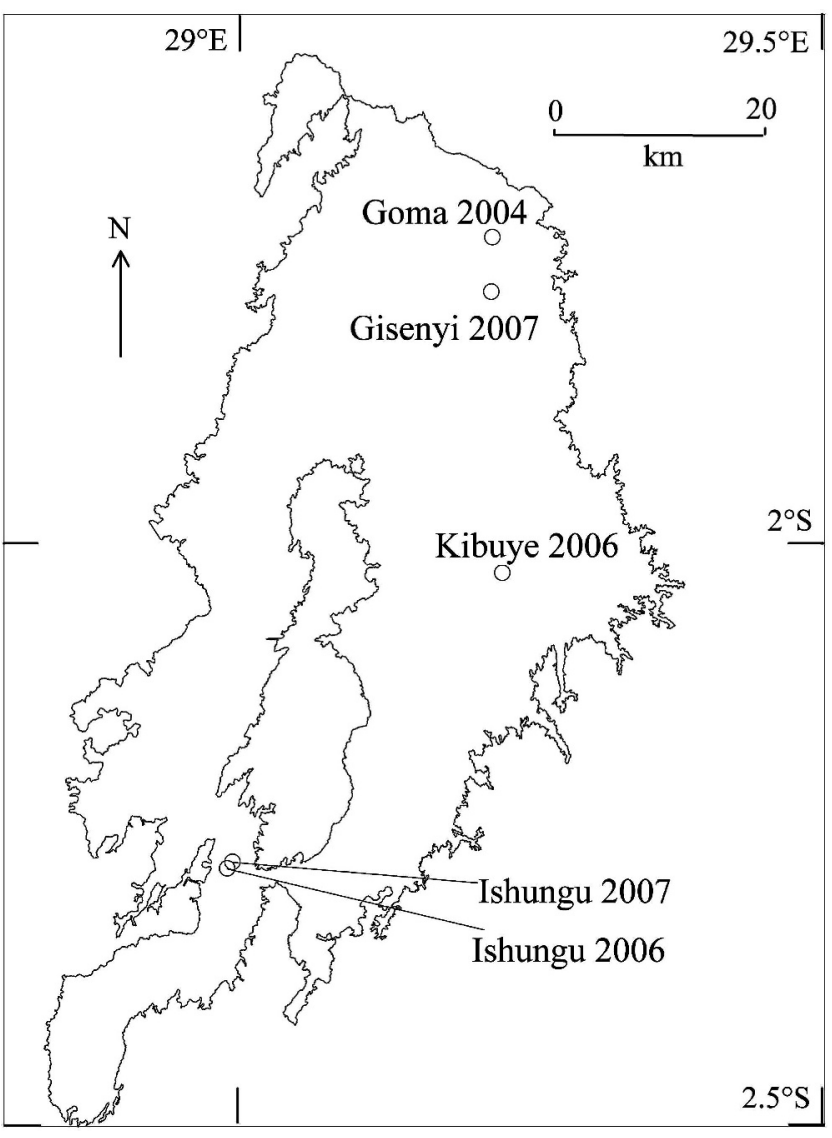

Fig. 1. Map of Lake Kivu showing the five locations for water sampling with circles. In the deep basin, the names of the three stations Goma (26 Feb 04), Gisenyi (12 May 07), and Kibuye (05 May 06) represent the nearest city followed by its sampling year. In Ishungu basin, water samples were taken at the same site for two consecutive years (17 May 07 and 15 May 06).

subaquatic inputs because they were somewhat independent of biological processes and the settling of particulate matter. Therefore, the vertical distribution of these ions was used as a reference for the chemical parameters influenced by the processes of assimilation and mineralization (such as the nutrients $\mathrm{P}, \mathrm{N}$, and $\mathrm{Si}$ ) or precipitation and dissolution (like the elements $\mathrm{Ca}^{2+}, \mathrm{Mg}^{2+}, \mathrm{Sr}^{2+}$, and $\left.\mathrm{Ba}^{2+}\right)$. The calculation of upward fluxes of major ions and nutrients allows estimating the composition of subaquatic inputs and quantifying the biological turnover rates of $\mathrm{N}$, $\mathrm{P}$, and Si. Upward nutrient fluxes to the trophic layer will be related to uptake rates by phytoplankton and compared with values from Lakes Malawi and Tanganyika. Furthermore, Lake Kivu has a huge reservoir of permanent anoxic waters and clearly defined redox gradients in which processes such as aerobic and anaerobic methane oxidation can act as biogeochemical sinks for nutrients and methane. To assess the importance of this sink, previously published $\mathrm{CH}_{4}$ fluxes (Tietze 1978; Schmid et al. 2005) will be compared with fluxes of $\mathrm{SO}_{4}^{2}$ and $\mathrm{O}_{2}$.

\section{Methods}

Sampling and chemical analyses Sampling was conducted during three field campaigns in February 2004, May 2006, and May 2007 at three different locations in the deep basin and in May 2006 and 2007 in the Ishungu basin of Lake Kivu (Fig. 1; Table 1). Water samples were collected with 5 -liter Niskin bottles. For depths below $200 \mathrm{~m}$, the open valve at the top of the Niskin bottle was capped with a balloon to prevent sample loss from vigorous outgassing during ascent. Immediately, one sample was taken for the determination of $\mathrm{O}_{2}$ by Winkler titration, and $1 \mathrm{~mL}$ of water was conserved in $1 \mathrm{~mL}$ of a solution of $4 \% \mathrm{Zn}$ acetate in $2 \%$ acetic acid for the photometric measurement of S(-II) within $24 \mathrm{~h}$. Unfiltered water $(10 \mathrm{~mL})$ was acidified with $200 \mu \mathrm{L}$ of suprapure concentrated $\mathrm{HNO}_{3}$ for cation analyses. For the determination of $\mathrm{SO}_{4}^{2}, 100 \mathrm{~mL}$ of water was acidified with $200 \mu \mathrm{L}$ of concentrated $\mathrm{HCl}$ and stirred vigorously for $3 \mathrm{~min}$ to remove $\mathrm{H}_{2} \mathrm{~S}$ from the solution and to prevent possible oxidation of $\mathrm{H}_{2} \mathrm{~S}$ in the samples. Additional water was sampled in a $250-\mathrm{mL}$ plastic bottle for the analysis of nutrients and alkalinity. Vertical profiles of water temperature, conductivity, and $\mathrm{pH}$ were recorded in situ with a Seabird SBE-19 conductivity, temperature, and depth (CTD) probe.

Water samples were filtered through $0.45-\mu \mathrm{m}$ Whatman disc filters within $24 \mathrm{~h}$ at temporary field stations in Kibuye and Gisenyi, as well as at the permanent laboratory of the Institut Supérieur Pédagogique in Bukavu. Standard methods (DEW 2004) were applied for colorimetric analyses of dissolved inorganic phosphorus (DIP), $\mathrm{NH}_{4}^{+}$, $\mathrm{SiO}_{2}, \mathrm{SO}_{4}^{2}$, and $\mathrm{S}(-\mathrm{II})$ with a portable photometer (Merck Nova 60). Alkalinity was titrated with the use of a 716 DMS Titrino (Metrohm) and $0.1 \mathrm{~mol} \mathrm{~L}{ }^{1} \mathrm{HCl} . \mathrm{NO}_{3}$ was measured with a flow-injection analyzer (FIA, Procon AG) by reduction of $\mathrm{NO}_{3}$ to $\mathrm{NO}_{2}$ on a cadmium reductor and detection of $\mathrm{NO}_{2}$ with a standard colorimetric method the use of sulfanilamide and $N$-(1-naphytyl)-ethylenediammonium chloride (DIN EN 26777:1993). Major cations were

Table 1. Description of the five sampling sites. The last column summarizes measured profiles, which were omitted in this publication because of unsatisfactory quality.

\begin{tabular}{|c|c|c|c|c|c|}
\hline Station name & Sampling date & Longitude E & Latitude S & Maximum depth (m) & $\begin{array}{l}\text { Excluded profile for } \\
\text { average concentrations }\end{array}$ \\
\hline Goma & $26 \mathrm{Feb} 04$ & $29^{\circ} 13.038^{\prime}$ & $1^{\circ} 44.469^{\prime}$ & 420 & $\mathrm{Mg}, \mathrm{H}_{2} \mathrm{~S}, \mathrm{Ca}$ \\
\hline Kibuye & 09 May 06 & $29^{\circ} 13.548^{\prime}$ & $2^{\circ} 01.684^{\prime}$ & 340 & $\mathrm{Na}$ \\
\hline Ishungu & 15 May 06 & $28^{\circ} 59.456^{\prime}$ & $2^{\circ} 16.134^{\prime}$ & 160 & $\mathrm{Na}$ \\
\hline Gisenyi & 12 May 07 & $29^{\circ} 12.983^{\prime}$ & $1^{\circ} 47.270^{\prime}$ & 440 & $\mathrm{H}_{2} \mathrm{~S}(>180 \mathrm{~m})$ \\
\hline Ishungu & 17 May 07 & $28^{\circ} 59.731^{\prime}$ & $2^{\circ} 16.501^{\prime}$ & 150 & \\
\hline
\end{tabular}



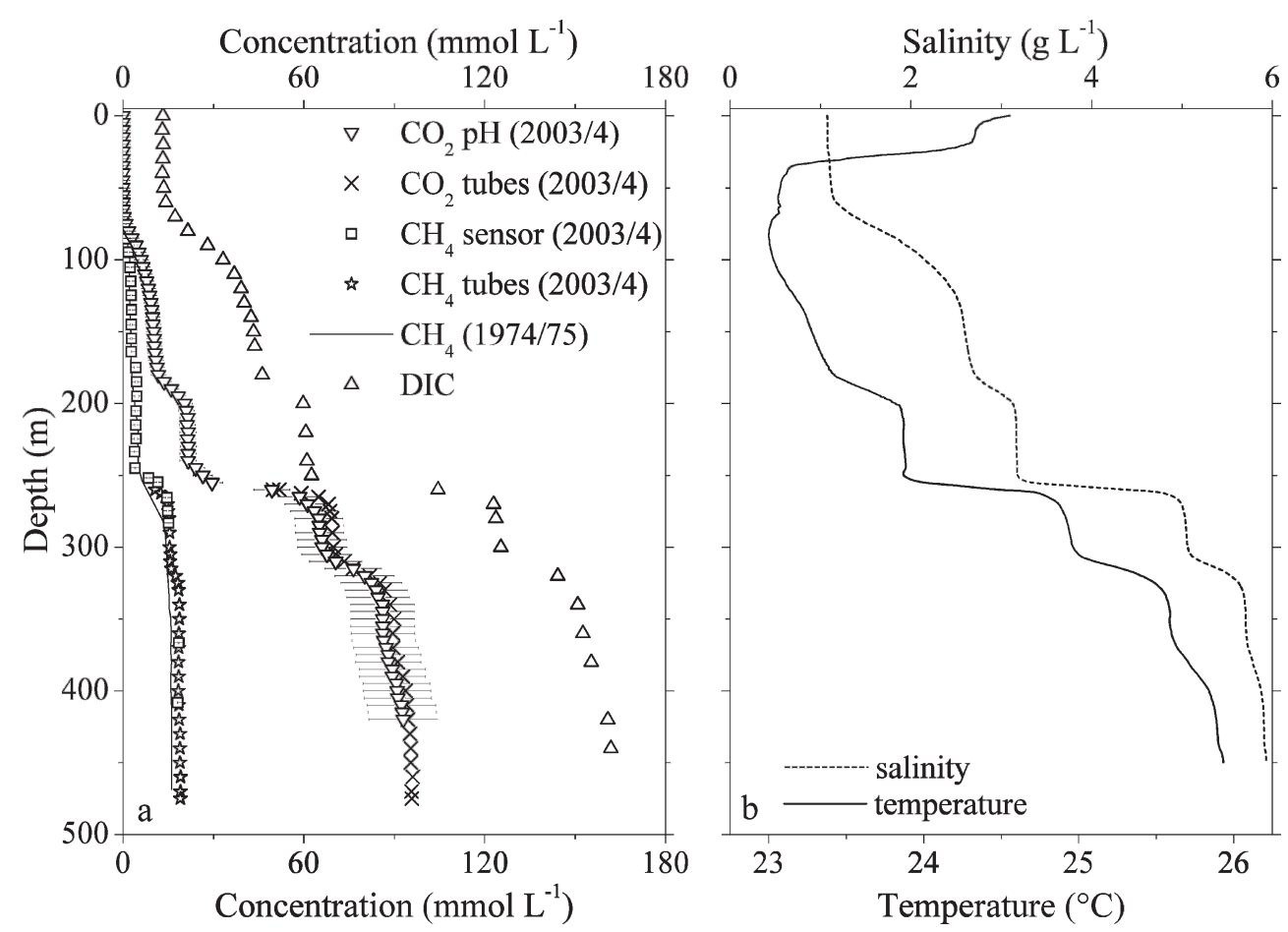

Fig. 2. (a) Vertical profiles of $\mathrm{CO}_{2}$ and $\mathrm{CH}_{4}$ from published data of Schmid et al. (2005), in which the two gases were measured by two independent methods in November 2003 and 2004. $\mathrm{CH}_{4}$ is also compared with the interpolation line of measurements made by Tietze (1978). Dissolved inorganic carbon was calculated in our study from these published $\mathrm{CO}_{2}$ profiles and our $\mathrm{pH}$ and alkalinity measurements. (b) Averaged vertical profiles of salinity and temperature were measured with a Seabird SBE 19 CTD probe in February 2004 (Schmid et al. 2005).

measured at Eawag in Switzerland by inductively coupled plasma optical emission spectrometry (SPECTROCIROS), and chloride was determined on a Metrohm ion chromatograph (733 IC Separator Center, 732 IC Detector, 762 IC Interface). Schmid et al. (2005) measured $\mathrm{CH}_{4}$ and $\mathrm{CO}_{2}$ by transferring water through a polyethylene tube to the surface, where gas and water were separated and their flow rates and concentrations were measured with a GA2000 infrared gas analyzer. Methane was also measured with a Capsum METS methane sensor (Fig. 2).

For data interpretation, chemical analyses of doubtful quality and outliers (mainly in 2004; see Table 1), were discarded. To make chemical profiles comparable and identify potential sources and sinks, the cumulative mass for each element was calculated as a function of depth as the vertically integrated mass divided by the total mass in the lake. Cumulative graphs for each substance were obtained by summing up values and range from $0 \%$ at the lake bottom to $100 \%$ at the surface.

Flux calculation The vertical flux of any water constituent, $F_{\text {total }}$, is composed of turbulent diffusion and advection

$$
F_{\text {total }}=-D_{\text {turbulent }} \frac{\overline{\Delta C}}{\Delta z}+\overline{C \times \mathrm{Adv}}
$$

where $D_{\text {turbulent }}$ is the turbulent diffusion coefficient $\left(\mathrm{m}^{2} \mathrm{~s}^{1}\right), \overline{\Delta C} / \Delta z$ refers to the vertical concentration gradient of the constituent ( $\mathrm{mol} \mathrm{m}^{4}$ ), Adv denotes the upwelling velocity ( $\mathrm{m} \mathrm{s}^{1}$ ), and $C$ stands for the concentration of the constituent at the given depth ( $\mathrm{mol} \mathrm{m}^{3}$ ). The overlying bars indicate an averaging over the whole depth range.

We determined the diffusive fluxes in four selected depth sections of Lake Kivu. Depth intervals for theses gradients were identified from conductivity profiles and ranged from 60 to $110 \mathrm{~m}, 110$ to $200 \mathrm{~m}, 255$ to $261 \mathrm{~m}$, and 270 to $440 \mathrm{~m}$. Concentration gradients were estimated from profiles of major ions, nutrients, and methane by fitting a linear regression to the concentrations observed in the chosen depth interval. An exception to this calculation concerns the main chemocline between 255 and $261 \mathrm{~m}$, where the vertical resolution of measured samples was not sufficient to determine the gradients. The precise depth range of this steep gradient layer was determined with the use of CTD conductivity profiles that were converted to salinity. A sharp change of $1.31 \mathrm{~g} \mathrm{~L}^{1}$ in salinity occurred within $5.9 \mathrm{~m}$ between 255.5 and $261.4 \mathrm{~m}$. The gradients of other substances across the gradient layer were calculated as the difference between the average concentrations in the nearly homogeneous layers above (200 $250 \mathrm{~m})$ and below (270 $300 \mathrm{~m}$ ) the chemocline, divided by $5.9 \mathrm{~m}$. Turbulent diffusion coefficients and the advection caused by subaquatic springs were estimated by the one-dimensional 

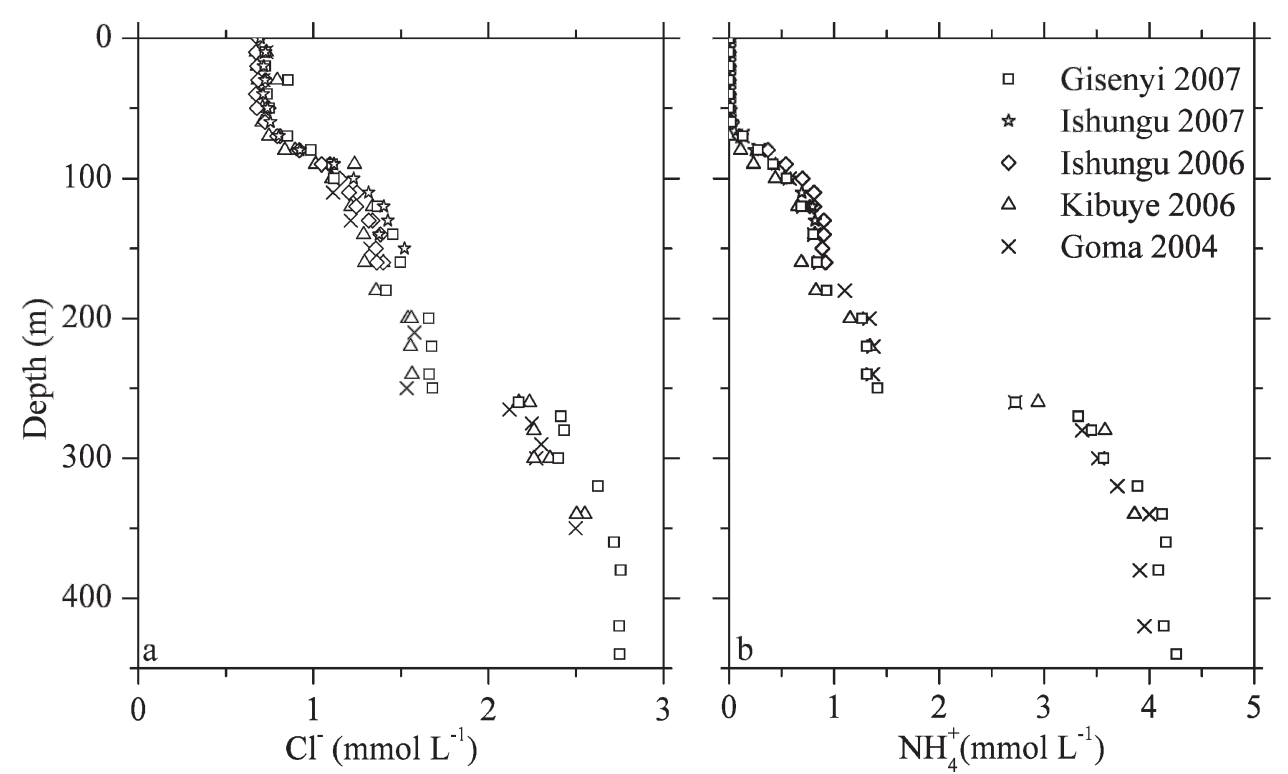

Fig. 3. Vertical profiles of (a) $\mathrm{Cl}$ and (b) $\mathrm{NH}_{4}^{+}$concentrations measured at the five sampling sites.

diffusion advection model described by Schmid et al. (2005). These diffusivity coefficients, determined with a resolution of $1 \mathrm{~m}$, were then averaged for each depth range. For the advective fluxes, concentration at each depth was multiplied with its respective advection coefficient and then averaged for each depth range. In the major chemocline, the total fluxes compared within $10 \%$ with the advective fluxes of the homogeneous layer from 270 to $300 \mathrm{~m}$, which correspond to the mean flux entering the major chemocline.

\section{Results}

Concentration profiles The concentration profiles of all components (except $\mathrm{Mn}^{2+}$ ) measured in the water column of Lake Kivu displayed a very similar pattern with abrupt changes at the two chemoclines $(67130 \mathrm{~m}$ and 255 $261 \mathrm{~m}$ ), as well as a stepwise rise in the intermediate layer. This supports the concept of a well-developed and stable stratification, which is mainly sustained by salinity and dissolved gases (Tietze 1978; Schmid et al. 2004). Our chemical profiles generally agree well with another recent study on the water chemistry of Lake Kivu (Tassi et al. 2009), but our $\mathrm{Ca}^{2+}$ and $\mathrm{Mg}^{2+}$ concentrations were slightly higher. Concentrations above $60 \mathrm{~m}$ were more variable and depended on the thickness of the mixed layer, which was seasonally influenced by strong winds (Sarmento et al. 2006). The oxycline varies between 30 and $60 \mathrm{~m}$ as a consequence of the seasonal mixing processes, and it was situated at around $40 \mathrm{~m}$ during our measurements. The $\mathrm{NO}_{3}$ profile is characterized by a peak at the oxycline with maximum concentrations of only $6 \mu \mathrm{mol} \mathrm{L}{ }^{1}$. Chemical profiles were remarkably similar regardless of location and sampling time. Concentration profiles of the conservative $\mathrm{Cl}$ ion observed at five different locations were equal within instrumental errors (Fig. 3a). Ammonium (Fig. 3b), as well as all other species measured at different locations, showed very similar concentrations independent of the geographical location, consistent with the very long residence time of the stratified layers. Horizontal homogeneity is confirmed by vertical conductivity profiles from different locations, indicating significant deviations only in the Gulf of Kabuno, which is separated from the lake by a shallow sill (Tassi et al. 2009), and in the deep water of Bukavu Bay (data not shown). Thus, for this study, we averaged concentrations measured at five locations and included standard deviations as error bars (Fig. 4).

Nonbiogenic, conservative elements like $\mathrm{Cl}$ and $\mathrm{Na}^{+}$ are excellent tracers, in that their vertical concentration pattern is driven by physical mixing and subaquatic inputs in the lake. In this section, we analyze how the profiles of divalent cations like $\mathrm{Mg}^{2+}, \mathrm{Ca}^{2+}, \mathrm{Sr}^{2+}$, and $\mathrm{Ba}^{2+}$ compare with the nonreactive elements. $\mathrm{Na}^{+}$and $\mathrm{Mg}^{2+}$ are the most abundant cations in Lake Kivu (3.80 $21.5 \mathrm{mmol} \mathrm{L}{ }^{1}$; Fig. 4d). In the epilimnion, $\mathrm{Na}^{+}$concentration was on average $10 \%$ higher than $\mathrm{Mg}^{2+}$, whereas below $300 \mathrm{~m}$, $\mathrm{Mg}^{2+}$ slightly dominated. Similarly, $\mathrm{Ca}^{2+}$ was depleted at the surface and enriched in the deep water to a higher extent than $\mathrm{Cl}$ (Fig. 4h). Both elemental patterns indicate a transfer of $\mathrm{Ca}^{2+}$ and $\mathrm{Mg}^{2+}$ from the epilimnion to the deep water by the process of biogenic precipitation, settling, and redissolution of carbonaceous particles. $\mathrm{Sr}^{2+}$ and $\mathrm{Ba}^{2+}$ (Fig. 4e) are also present in Lake Kivu at significant concentrations, probably because of high weathering rates of volcanic rocks (Ojiambo et al. 2003). Their profiles were similar and were characterized by uniform concentrations below $280 \mathrm{~m}$ and depleted concentrations in the surface layer.

Nutrient concentrations also rose in a stepwise fashion with depth and changed abruptly at the two chemoclines. DIP and $\mathrm{NH}_{4}^{+}$concentrations were below the detection limit $\left(<0.1 \mu \mathrm{mol} \mathrm{N} \mathrm{L}{ }^{1}\right.$ and $\left.0.03 \mu \mathrm{mol} \mathrm{P} \mathrm{L}^{1}\right)$ in the euphotic zone, whereas the nutrients were extremely 

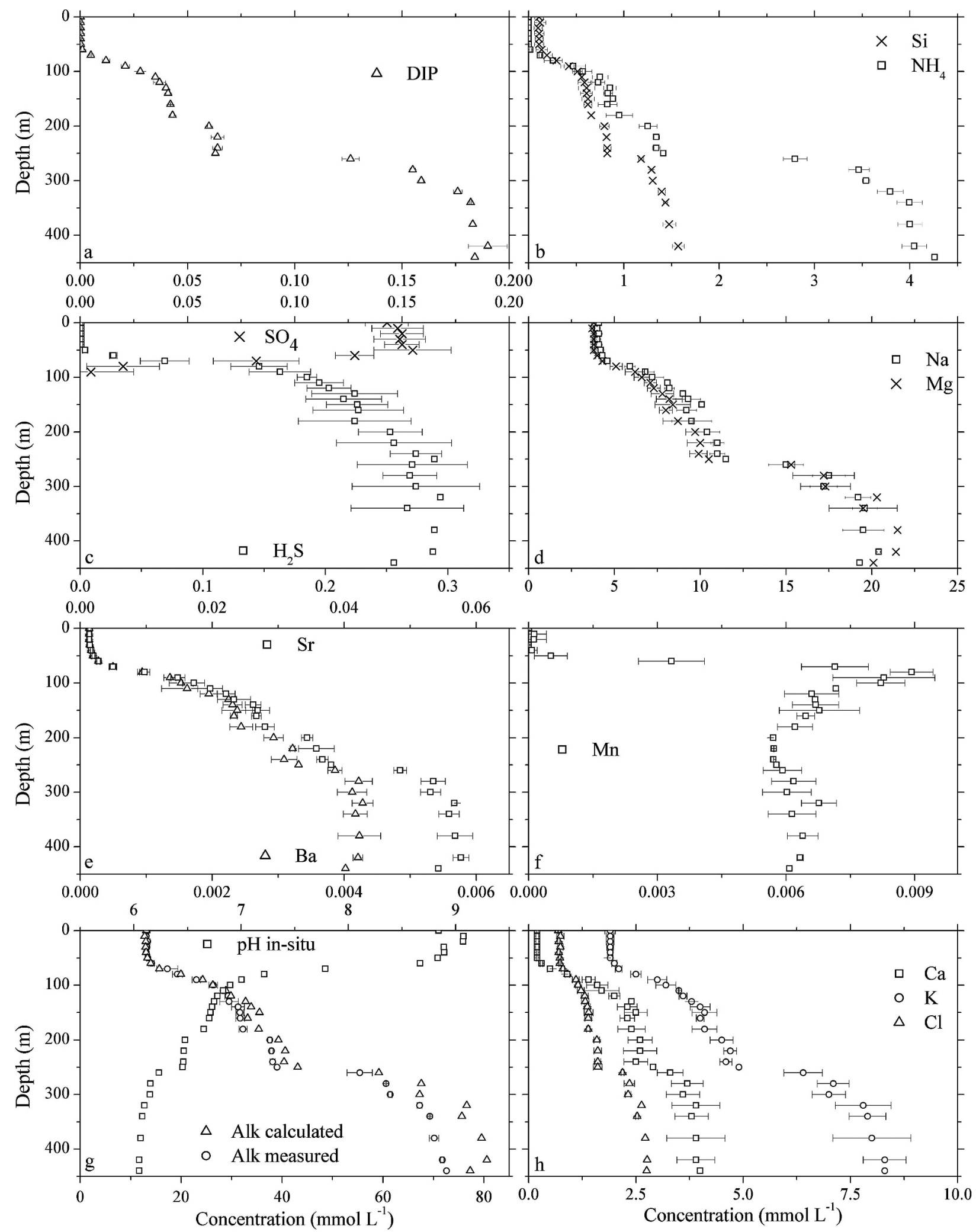

Fig. 4. Profiles of nutrients and majors elements $\left(\mathrm{mmol} \mathrm{L}^{1}\right)$ averaged for the five sampling sites. Error bars represent standard deviations of these five measurements. (a) DIP; (b) $\mathrm{Si}$ and $\mathrm{NH}_{4}^{+}$; (c) $\mathrm{SO}_{4}^{2-}$ and $\mathrm{H}_{2} \mathrm{~S}$; (d) $\mathrm{Na}^{+}$and $\mathrm{Mg}^{2+}$; (e) $\mathrm{Sr}^{2+}$ and $\mathrm{Ba}^{2+}$; (f) $\mathrm{Mn}^{2+}$; (g) comparison between measured alkalinity and charge balance of anions and cations, as well as in situ pH measured with a CTD probe; and (h) $\mathrm{Ca}^{2+}, \mathrm{K}^{+}$, and $\mathrm{Cl}$. 
Table 2. Coefficients of turbulent diffusivity and vertical advection as used for upward flux calculations. These values are derived from the one dimensional diffusion advection model, as described by Schmid et al. (2005).

\begin{tabular}{|c|c|c|}
\hline $\begin{array}{l}\text { Depth } \\
\text { range }(\mathrm{m})\end{array}$ & $\begin{array}{l}\text { Turbulent diffusivity } \\
\qquad\left(\mathrm{m}^{2} \mathrm{~s}\right.\end{array}$ & $\begin{array}{l}\text { Vertical advection } \\
\left(\begin{array}{lll}\mathrm{m} \mathrm{s}^{1}\end{array}\right)\end{array}$ \\
\hline $60 \quad 110$ & $1.0( \pm 0.8) \times 10 \quad 6$ & $2.2( \pm 0.1) \times 108$ \\
\hline 110200 & $4.9( \pm 8.3) \times 10 \quad 8$ & $2.5( \pm 0.4) \times 108$ \\
\hline 255261 & $1.5( \pm 0.1) \times 10 \quad 8$ & $5.3( \pm 2.0) \times 109$ \\
\hline 270440 & $3.2( \pm 2.2) \times 10 \quad 8$ & $5.2( \pm 0.8) \times 109$ \\
\hline
\end{tabular}

enriched in the deep water $\left(0.19 \mathrm{mmol}\right.$ DIP $\mathrm{L}^{1}$ and $4.26 \mathrm{mmol} \mathrm{NH}_{4}^{+} \mathrm{L} \quad{ }^{1}$; Fig. 4a,b). By comparison, $\mathrm{SiO}_{2}$ was less depleted in the epilimnion $\left(0.11 \mathrm{mmol} \mathrm{L}{ }^{1}\right)$ and showed a less pronounced maximum $\left(1.57 \mathrm{mmol} \mathrm{L}{ }^{1}\right)$. The $\mathrm{N}: \mathrm{Si}: \mathrm{P}$ ratio in the hypolimnion calculated from linear regressions below $100 \mathrm{~m}$ was $22: 6.5: 1$. The constant proportionality between DIP and $\mathrm{NH}_{4}^{+}$throughout the whole water column suggests that the long-term stoichiometry of mineralized sinking organic material was responsible for their enrichment in the deep water. Additional biogeochemical processes affecting $\mathrm{N}$ and $\mathrm{P}$ stoichiometries at different depths below $100 \mathrm{~m}$ were apparently of minor importance.

By contrast, $\mathrm{S}(-\mathrm{II})$ and $\mathrm{Mn}^{2+}$ distributions differed completely from those of other elements. The $\mathrm{Mn}^{2+}$ profile was characterized by a distinct peak at the oxycline, where the reductive dissolution of manganese oxides released dissolved $\mathrm{Mn}^{2+}$ (Fig. 4f). Below $160 \mathrm{~m}, \mathrm{Mn}^{2+}$ concentrations were constant at around $6.3 \mu \mathrm{mol} \mathrm{L} 1$. The sulfur distribution was governed by the redox couple $\mathrm{SO}_{4}^{2}$ and $\mathrm{S}(-\mathrm{II})$ (Fig. 4c). In the oxic layer, $\mathrm{SO}_{4}^{2}$ dominated with a maximum concentration of $0.14 \mathrm{mmol} \mathrm{L}{ }^{1}$. Below the oxycline, $\mathrm{SO}_{4}^{2}$ decreased with a sharp gradient and disappeared to levels below detection at $90 \mathrm{~m}$. Compared with $\mathrm{SO}_{4}^{2}$, the $\mathrm{S}(-\mathrm{II})$ profile showed a mirror image: $\mathrm{S}(-\mathrm{II})$ was absent above the oxycline, increased sharply between 50 and $150 \mathrm{~m}$ depth, and then remained constant at an average concentration of $0.27 \mathrm{mmol} \mathrm{L} 1$. Recent published data in which $\mathrm{SO}_{4}^{2}$ was detected throughout the anoxic water column (Tassi et al. 2009) seems to have been contaminated with $\mathrm{O}_{2}$.

Extreme $\mathrm{CO}_{2}$ enrichment in the hypolimnion in Lake Kivu and high alkalinity governed the $\mathrm{pH}$ profile. At a level of $90 \mathrm{mmol} \mathrm{L}{ }^{1} \mathrm{CO}_{2}$, in situ conditions were characterized by $\mathrm{pH} 6.1$ at $450 \mathrm{~m}$ water depth. The course of alkalinity followed the pattern of base cations and reached a maximum level of $72.6 \mathrm{mmol} \mathrm{L} 1$ at $440 \mathrm{~m}$ depth. Alternatively, alkalinity could be calculated from the balance of cation and anion charges (Fig. $4 \mathrm{~g}$ ) and showed, within the uncertainty of the analysis, results comparable to the titrated alkalinity (difference was $<8 \%$ ).

Upward fluxes Coefficients for turbulent diffusivity and vertical advection (Table 2) were determined by a diffusive advective model, which satisfactorily reproduced methane and salinity profiles (Schmid et al. 2005). The main uncertainty of this model is from estimation of the discharge of subaquatic springs at six different depths, driving upward advection. Because the $\mathrm{O}_{2}$ and $\mathrm{SO}_{4}^{2}$ composition of the springs is unknown, the model discarded methane oxidation at the major chemocline. If significant oxidation takes place, a reduced discharge for the spring would be required to explain $\mathrm{CH}_{4}$ removal. This questionable scenario would modify the repartition between advection and diffusion, but the total upward fluxes would remain similar because they are well constrained by the salt budget of the epilimnion. With current knowledge, the physical parameters can therefore be considered good estimates.

The calculated upward fluxes of water constituents were mainly due to advection, whereas fluxes from turbulent diffusion contributed only to a small extent, mainly in the chemoclines. As a result of wind forcing, the vertical diffusivity above $110 \mathrm{~m}$ is larger by two orders of magnitude (Table 2). The concentration gradients in the major chemoclines at $255261 \mathrm{~m}$ and the upper chemocline at $67130 \mathrm{~m}$ were 40 and 3.5 times higher, respectively, than for the intermediate layers (Table 3). As a consequence, turbulent diffusion contributed between $30 \%$ and $60 \%$ of total upward fluxes in the upper chemocline but only $1530 \%$ in the major chemocline. In comparison, the upwelling velocity is four times higher above $200 \mathrm{~m}$ (Table 2), and advection mainly drove total upward fluxes for the two intermediate layers $(>98 \%)$ and the major chemocline (70 85\%).

Upward fluxes for the major ions were higher above $200 \mathrm{~m}$ than below $255 \mathrm{~m}$. Fluxes for layers $60110 \mathrm{~m}$ and $110200 \mathrm{~m}$ were similar and about three times higher than the homogeneous fluxes for layers 255261 and $270440 \mathrm{~m}$. This pattern was common for the conservative cations, volcanic cations, and $\mathrm{Ca}^{2+}$ and $\mathrm{Mg}^{2+}$, suggesting additional sources between 200 and $255 \mathrm{~m}$. This additional source probably originated from the subaquatic spring situated at

Table 3. Gradients for major ions, nutrients, and gases, determined as the slope of linear regression from measured concentrations in four different layers.

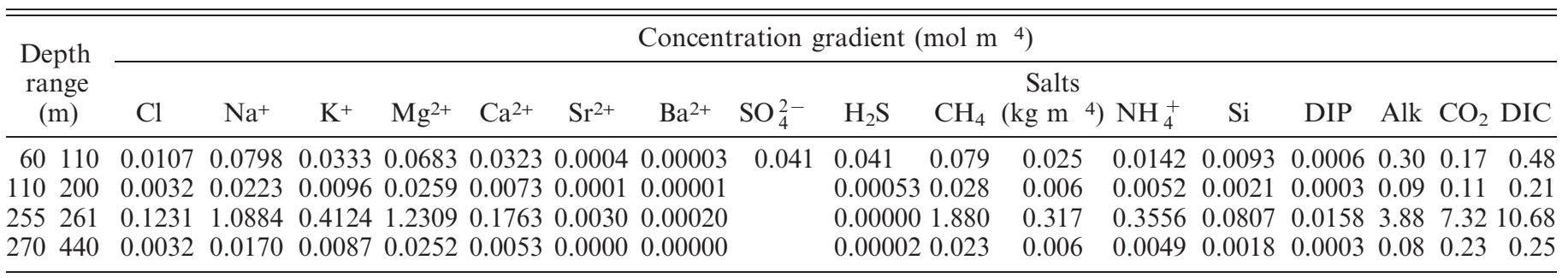


Table 4. Total upward fluxes for major ions, nutrients, and gases, calculated as the sum of diffusive and advective fluxes. Fluxes from the subaquatic spring at $250 \mathrm{~m}$ are calculated as the difference between average fluxes above $200 \mathrm{~m}$ and below $255 \mathrm{~m}$.

\begin{tabular}{|c|c|c|c|c|c|c|c|c|c|c|c|c|c|c|c|c|c|}
\hline \multirow{2}{*}{$\begin{array}{l}\text { Depth } \\
\text { range } \\
(\mathrm{m})\end{array}$} & \multicolumn{17}{|c|}{ Flux (mmol m $\left.2 \mathrm{~d}^{1}\right)$} \\
\hline & $\mathrm{Cl}$ & $\mathrm{Na}^{+}$ & $\mathrm{K}^{+}$ & $\mathrm{Mg}^{2+}$ & $\mathrm{Ca}^{2+}$ & $\mathrm{Sr}^{2+}$ & $\mathrm{Ba}^{2+}$ & $\mathrm{SO}_{4}^{2-}$ & $\mathrm{H}_{2} \mathrm{~S}$ & $\mathrm{CH}_{4}$ & $\begin{array}{c}\text { Salts } \\
\left(\mathrm{g} \mathrm{m}^{2} \mathrm{~d}^{1}\right)\end{array}$ & $\mathrm{NH}_{4}^{+}$ & DIP & $\mathrm{Si}$ & Alk & $\mathrm{CO}_{2}$ & DIC \\
\hline 60110 & 2.8 & 18.9 & 8.2 & 16.2 & 4.9 & 0.055 & 0.0047 & 0.27 & 0.61 & 9.38 & 5.6 & 1.95 & 0.086 & 1.50 & 67 & 22 & 91 \\
\hline 110200 & 2.9 & 19.5 & 8.4 & 17.3 & 4.9 & 0.055 & 0.0047 & & 0.46 & 7.05 & 5.4 & 1.87 & 0.089 & 1.33 & 66 & 27 & 93 \\
\hline 255261 & 1.1 & 7.9 & 3.2 & 7.5 & 1.7 & 0.024 & 0.0019 & & 0.11 & 7.27 & 2.3 & 1.55 & 0.070 & 0.58 & 28 & 29 & 56 \\
\hline 270440 & 1.2 & 9.0 & 3.7 & 8.0 & 1.8 & 0.026 & 0.0019 & & 0.11 & 8.32 & 2.6 & 1.84 & 0.083 & 0.66 & 32 & 37 & 69 \\
\hline $\begin{array}{c}60200 \\
\quad \text { (average) } \\
255440\end{array}$ & 2.9 & 19.2 & 8.3 & 16.8 & 4.9 & 0.055 & 0.0047 & & 0.54 & 8.13 & 5.5 & 1.91 & 0.087 & 1.41 & 67 & 24 & 92 \\
\hline (average) & 1.1 & 8.4 & 3.4 & 7.7 & 1.7 & 0.025 & 0.0019 & & 0.11 & 7.50 & 2.5 & 1.70 & 0.077 & 0.62 & 30 & 33 & 63 \\
\hline Source, 250 & 1.7 & 10.8 & 4.8 & 9.1 & 3.2 & 0.030 & 0.0028 & & 0.43 & 0.62 & 3.1 & 0.21 & 0.010 & 0.79 & 37 & 9 & 29 \\
\hline
\end{tabular}

$250 \mathrm{~m}$, sustaining the major chemocline. Fluxes from this subaquatic spring were calculated as the differences between fluxes above $200 \mathrm{~m}$ and below $255 \mathrm{~m}$ (Table 4). This behavior with two distinct fluxes can also be observed for alkalinity and dissolved inorganic carbon (DIC), indicating their presence in the spring. In contrast, $\mathrm{CO}_{2}$ had an opposite distribution, characterized by lower upward fluxes above the major chemocline. Regardless of the uncertainties, these lower fluxes probably indicate a shift from $\mathrm{CO}_{2}$ to $\mathrm{HCO}_{3}$ because of different carbonate compositions of the spring.

The upward fluxes of nutrients $\mathrm{NH}_{4}^{+}\left(1.80 \mathrm{mmol} \mathrm{m}^{2} \mathrm{~d}^{1}\right)$ and DIP $\left(0.082 \mathrm{mmol} \mathrm{m} 2 \mathrm{~d}^{1}\right)$ were constant throughout the water column. These constant fluxes seem to indicate that the subaquatic springs introduce no additional nutrients. However, given the increasing area of the lake, a constant source from the sediment is needed at each depth to maintain constant fluxes per area throughout the whole water column. By contrast, Si had an upward flux above $200 \mathrm{~m}\left(1.41 \mathrm{mmol} \mathrm{m}^{2} \mathrm{~d}^{1}\right)$, which was twice as high as its flux below $255 \mathrm{~m}\left(0.62 \mathrm{mmol} \mathrm{m}{ }^{2} \mathrm{~d} \quad{ }^{1}\right)$. These two distinct fluxes suggest that the subaquatic spring were enriched in $\mathrm{Si}$, probably through weathering of volcanic rocks. As with the other nutrients, Si needs a source from the sediment to maintain constant fluxes above or below the major chemocline.

Methane upward fluxes were constant throughout the water column $(8.00 \mathrm{mmol} \mathrm{m} 2 \mathrm{~d} 1)$, indicating that methane was absent from the subaquatic spring at $250 \mathrm{~m}$. However, it was a basic assumption of the physical model that no $\mathrm{CH}_{4}$ was introduced from the subaquatic springs. Anaerobic methane oxidation is possible above $100 \mathrm{~m}$, where $\mathrm{SO}_{4}^{2}$ appeared in the water column. However, $\mathrm{SO}_{4}^{2}$ flux $\left(0.27 \mathrm{mmol} \mathrm{m}^{2} \mathrm{~d} \quad 1\right)$ was one order of magnitude lower than the upward methane flux $(9.4 \mathrm{mmol} \mathrm{m} 2$ d ${ }^{1}$ ) between 60 and $110 \mathrm{~m}$ and could therefore account only for $3 \%$ of methane oxidation.

\section{Discussion}

In this section, we analyze the physical and biogeochemical processes influencing the distribution of the main nutrients and major ions in the water column. First, we assess the mixing processes in the lake on the basis of nonreactive tracers. In a second step, deviations from these tracer profiles are used to point out additional biogeochemical processes. Internal loading of nutrients via upward fluxes are then compared with published values from Lake Malawi and Lake Tanganyika and are related to uptake rates of phytoplankton. Finally, the origin and fate of methane is discussed in relation to the sulfur cycle and the nutrient cycles.

Location of subaquatic springs Mixing processes are mainly responsible for the distribution of major ions in the water column of Lake Kivu. The lake is permanently stratified and characterized by an extremely weak vertical turbulent diffusivity. Essentially, below $120 \mathrm{~m}$ depth, vertical fluxes are dominated by a slow upwelling caused by saline subaquatic springs flowing into its deep waters (Schmid et al. 2005). These subaquatic springs cause a replacement of water, which displaces the lake water vertically. Our analyses indicated that conservative tracers had a stronger upward flux above $200 \mathrm{~m}$ than below $255 \mathrm{~m}$. The additional subaquatic spring between 200 and $255 \mathrm{~m}$ explained these two distinct fluxes. A comparison of cumulative mass with the conservative $\mathrm{Cl}$ (Figs. 5, 6) illustrate positive peaks at $250 \mathrm{~m}$ depth for $\mathrm{Na}^{+}, \mathrm{K}^{+}, \mathrm{Mg}^{2+}$, and alkalinity, which means that a larger fraction of these elements was contained below this depth. In fact, $\mathrm{Cl}$ had a relatively stronger source at $250 \mathrm{~m}$ than the other elements. This depth of $250 \mathrm{~m}$ was also detected as one of six depths at which subaquatic springs enter the lake, on the basis of a one-dimensional diffusive advective model for $\mathrm{CH}_{4}$ and salinity (Schmid et al. 2005). With an estimated water discharge of $15 \mathrm{~m}^{3} \mathrm{~s}^{1}$ (Schmid et al. 2005), the concentrations calculated for this spring were smaller (by 8 29\%) than for the lake water at $250 \mathrm{~m}$ (Table 5). This dilution effect from the subaquatic spring was probably the cause of the major chemocline between 255 and $261 \mathrm{~m}$ that was observed in all chemical profiles.

Further evidence of subaquatic activities were also established in previous studies (Degens et al. 1972; Tietze 1978), in which Lake Kivu was interpreted as a mixture of two waterbodies. On the one hand, subaquatic springs were responsible for saline deep waters, whereas precipitation 

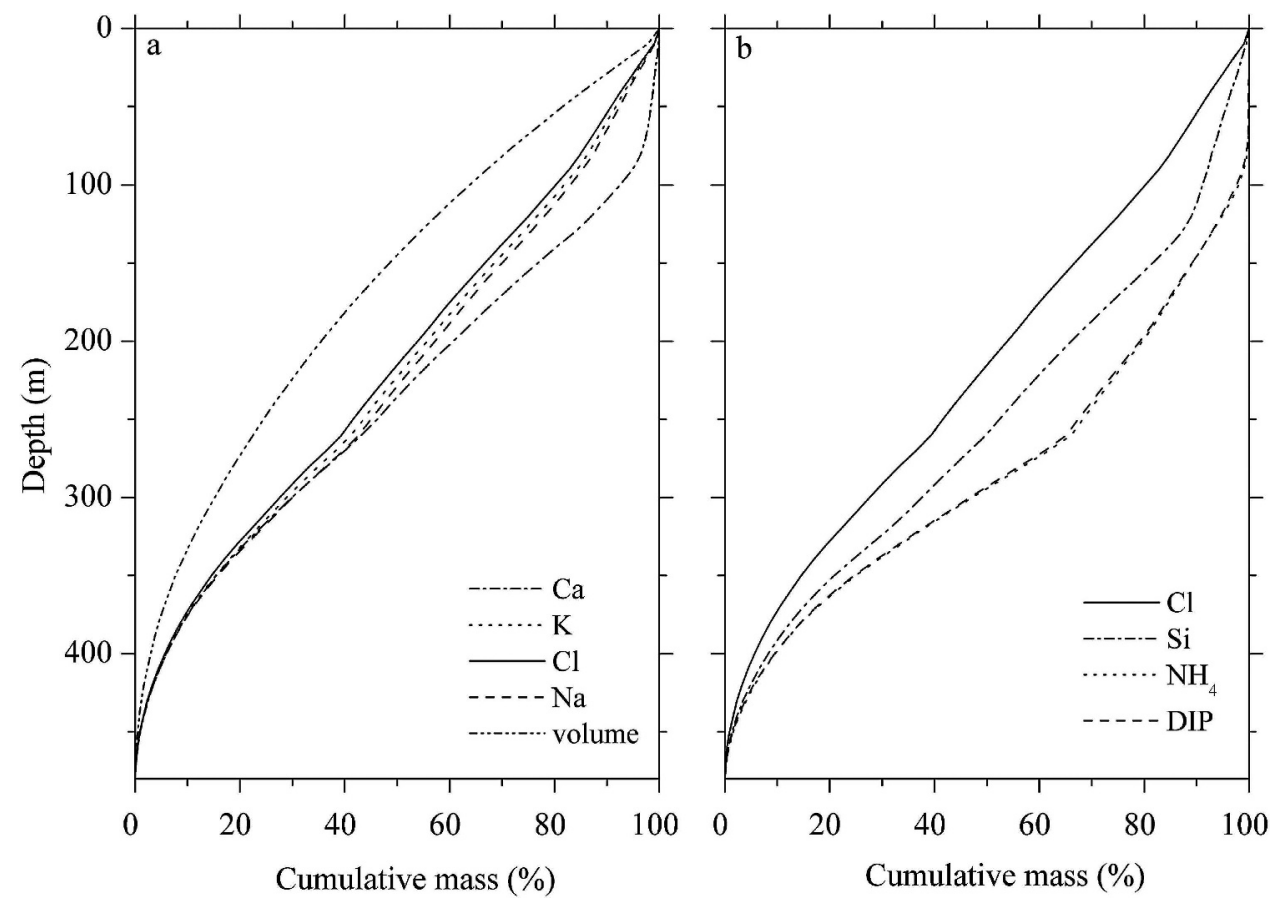

Fig. 5. Cumulative mass calculated as the average concentrations in each $10 \mathrm{~m}$ depth segment, multiplied by its respective volume, and divided by the total amount contained in the lake. This percentage contained in each $10 \mathrm{~m}$ interval was then summed up from the lake bottom $(0 \%)$ to the surface $(100 \%)$. (a) Cumulative mass for $\mathrm{Ca}^{2+}$, nonreactive tracers $\left(\mathrm{K}^{+}, \mathrm{Cl}, \mathrm{Na}^{+}\right)$, and water; (b) cumulative mass for $\mathrm{Cl}$ and nutrients $\left(\mathrm{Si}, \mathrm{NH}_{4}, \mathrm{DIP}\right)$.

depleted surface waters. A simple mixing model explained the distribution of principal elements, with surface waters low in salt and enriched in ${ }^{18} \mathrm{O}\left(\delta^{18} \mathrm{O}=3.5 \%\right)$ because of intense evaporation and deep waters rich in salts and depleted in ${ }^{18} \mathrm{O}\left(\delta^{18} \mathrm{O}=0.5 \%\right) .{ }^{18} \mathrm{O}$-depleted subaquatic springs were closer to precipitation $\left(\delta^{18} \mathrm{O}=3 \%\right)$ and seemed to originate from meteoric waters percolating underground and taking up salts. Similar $\mathrm{Na}^{+}: \mathrm{K}^{+}$ratios evidenced that the same groundwater system also fed Lake

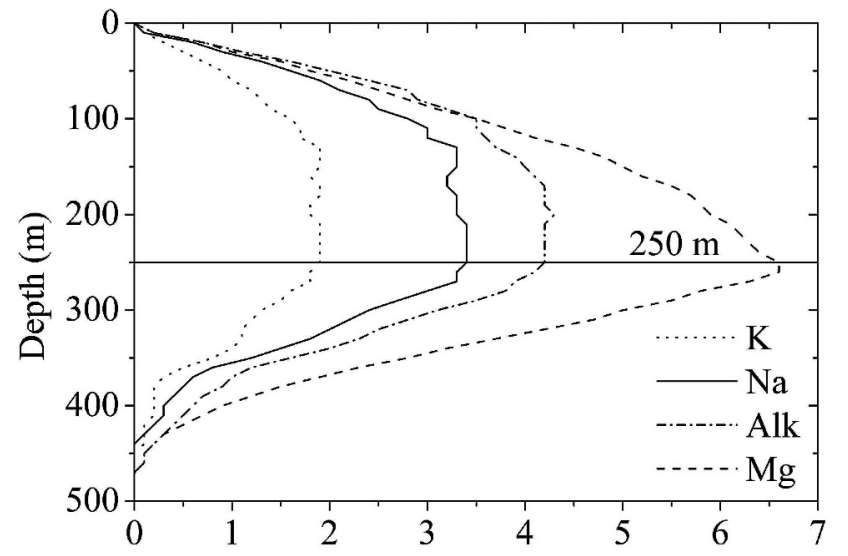

Cumulative mass of element - cumulative mass of $\mathrm{Cl}^{-}(\%)$

Fig. 6. Difference between cumulative mass (\%), as exempli fied in Fig. 5, of the components $\mathrm{K}^{+}, \mathrm{Na}^{+}$, alkalinity, and $\mathrm{Mg}^{2+}$ to the cumulative mass of $\mathrm{Cl}(\%)$.
Edward, Lake Albert, and Lake Kivu (Degens et al. 1972). Our recent data on $\mathrm{Na}^{+}: \mathrm{K}^{+}$agreed with these historic data. In addition, the observed proportionality of $\mathrm{K}^{+}, \mathrm{Na}^{+}$, and $\mathrm{Cl}$ concentrations throughout the water column $\left(\mathrm{Na}^{+}: \mathrm{K}^{+}: \mathrm{Cl}=8.3: 3.4: 1\right)$ supports this mixing model.

Carbonate precipitation and dissolution In addition to mixing, several elements were affected by the biogenic precipitation of calcite in the photic zone. Biogenic calcite precipitation could be influenced by picoplankton and phosphate concentrations (Dittrich and Obst 2004). The concentration ratio of $\mathrm{Ca}^{2+}$ between deep and surface waters was more than five times higher than those of the reference ions $\mathrm{Cl}, \mathrm{Na}^{+}$, or $\mathrm{K}^{+}$. Calculation of the saturation index for calcite (Stumm and Morgan 1996)

$$
\Omega=\log \frac{\left[\mathrm{Ca}^{2+}\right]\left[\mathrm{CO}_{3}^{2}\right]}{K_{\mathrm{s}_{0}}}
$$

where

$$
\begin{aligned}
\log K_{\mathrm{S}_{0}}= & -171.9065-0.077993 \times T \\
& +2839.319 / T+71.595 \times \log T
\end{aligned}
$$

(Plummer and Busenberg 1982) and $T$ is the absolute temperature $(\mathrm{K})$ showed that $\Omega$ was close to saturation throughout the water column, with a sharp increase above $60 \mathrm{~m}$ (Saturation Index $>1.1$; Fig. 7). Calcite was therefore supersaturated by more than a factor of 10 above 
Table 5. Concentrations in the subaquatic spring as determined by upward fluxes (Table 4) and an estimated discharge of $15 \mathrm{~m}^{3} \mathrm{~s} 1$ compared with concentrations observed in the lake water at $250 \mathrm{~m}$ depth.

\begin{tabular}{lcrlrrrrrrr}
\hline \hline & \multicolumn{7}{c}{ Concentration $\left(\mathrm{mmol} \mathrm{L}{ }^{1}\right)$} \\
\cline { 2 - 10 } & $\mathrm{Cl}$ & $\mathrm{Na}^{+}$ & $\mathrm{K}^{+}$ & $\mathrm{Mg}^{2+}$ & $\mathrm{Ca}^{2+}$ & $\mathrm{Si}$ & $\mathrm{Alk}^{2+}$ & $\mathrm{Sr}^{2+}$ & $\mathrm{Ba}^{2+}$ \\
\hline Source at $250 \mathrm{~m}$ & 1.45 & 9.1 & 4.1 & 7.6 & 2.7 & 0.66 & 31 & 0.025 & 0.0023 \\
Lake water at $250 \mathrm{~m}$ & 1.61 & 11.5 & 4.9 & 10.5 & 2.9 & 0.82 & 39 & 0.038 & 0.0033 \\
\hline
\end{tabular}

$60 \mathrm{~m}$, whereas it was close to equilibrium with the dissolved phase below. Calcite was therefore not redissolved during settling, as proven by calcite crystals found in some layers of Lake Kivu sediment cores (Degens and Kulbicki 1973; Botz et al. 1988). Recent sediment cores and sediment traps deployed in the water column confirmed the ongoing precipitation of calcite (N. Pasche unpubl.).

The ions $\mathrm{Sr}^{2+}$ and $\mathrm{Ba}^{2+}$ seemed to be affected by coprecipitation (Kim et al. 1999) because their concentration ratios between hypo- and epilimnion were also clearly higher than those of $\mathrm{Cl}, \mathrm{Na}^{+}$, or $\mathrm{K}^{+}$. A similar process could not, however, be concluded from the concentration profile of $\mathrm{Mg}^{2+}$, probably because coprecipitation would not be sufficient to significantly influence the much higher concentrations of $\mathrm{Mg}^{2+}$ compared with $\mathrm{Ca}^{2+}$.

Concentrations of S(-II) were constant below $160 \mathrm{~m}$ and revealed that a precipitation process removes $\mathrm{S}(-\mathrm{II})$ from the water column. A recent study (N. Pasche unpubl.) observed pyrite $(\mathrm{FeS})$ in Lake Kivu sediments. This observation was confirmed by similar export fluxes of $\mathrm{Fe}$ $\left(0.10 \mathrm{~mol} \mathrm{~m}^{2} \mathrm{yr}^{1}\right)$ and $\mathrm{S}\left(0.16 \mathrm{~mol} \mathrm{~m}^{2} \mathrm{yr}^{1}\right)$ in the sediment. The total amount of S(-II) integrated over the volume of the $300 \mathrm{~m}$ of anoxic water represents $45 \mathrm{~mol} \mathrm{~m}{ }^{2}$. Dividing the total amount with the export flux of S(-II) would result in a residence time of $280 \mathrm{yr}$ for $\mathrm{S}$, representing nearly a third of the deep-water residence time (800 $1000 \mathrm{yr})$. As such, pyrite precipitation can explain the constant concentrations observed for S(-II) below $160 \mathrm{~m}$.

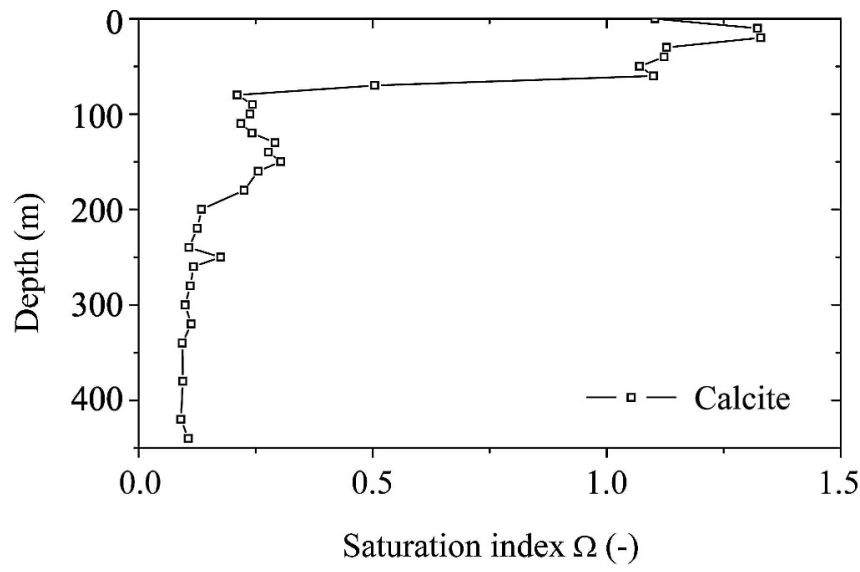

Fig. 7. Logarithm of the saturation index for calcite. The saturation index was calculated for each depth with the activity of $\mathrm{Ca}^{2+}$ and $\mathrm{CO}_{3}^{2-}$ and the solubility constant $K_{\mathrm{s}_{0}}$ (Plummer and Busenberg 1982).
Contrasting nutrient cycles: $N, P$, and $S i$ Contrary to temperate lakes in which seasonal deep mixing homogenizes the whole water column periodically, nutrient recycling in Lake Kivu occurs only through advective and diffusive transport from nutrient-rich deep waters to the epilimnion (Kilham and Kilham 1990). The resulting long residence time of $800 \mathrm{yr}$ allows an estimation of nutrient enrichment in the deep waters of Lake Kivu, carrying the signature of the average long-term stoichiometry of the sinking organic material and sediment mineralization $(\mathrm{N}: \mathrm{Si}: \mathrm{P}=22: 6.5: 1)$. The high $\mathrm{N}: \mathrm{P}$ ratio indicates $\mathrm{P}$ limitation.

Normalized cumulative mass of $\mathrm{N}, \mathrm{P}$, and $\mathrm{Si}$ indicate similar behavior of $\mathrm{NH}_{4}^{+}$and DIP, whereas $\mathrm{SiO}_{2}$ seems to have been influenced by different processes (Fig. $5 \mathrm{~b}$ ). $\mathrm{NH}_{4}^{+}$ and DIP had a strong sink above $90 \mathrm{~m}$ and a source below $260 \mathrm{~m}$, caused by assimilation in the photic zone, sedimentation, and mineralization in the bottom water and sediment. Contrary to major ions, fluxes of $\mathrm{NH}_{4}^{+}$and DIP were constant throughout the water column, suggesting no additional input from subaquatic springs at $250 \mathrm{~m}$. In contrast, $\mathrm{SiO}_{2}$ is not limiting for the production of diatoms and has a punctual spring at $250 \mathrm{~m}$ depth. The subaquatic spring at $250 \mathrm{~m}$ added $0.8 \mathrm{mmol} \mathrm{Si} \mathrm{m} 2 \mathrm{~d} 1$ (Table 4), from weathering of volcanic rocks embedding Lake Kivu. Si inputs in the deep water from mineralization appear to be more limited than for $\mathrm{N}$ and $\mathrm{P}$. A weaker degradation of diatom cells is confirmed by a ratio of BSi : P (4.1) and BSi : N (29.9) in sedimenting material higher than the same ratios $(0.6,12.5)$ in the deep water $(\mathrm{N}$. Pasche unpubl).

In permanently stratified lakes, internal loading via upward fluxes is of major importance for nutrient recycling and phytoplankton growth (Table 6). In Lake Malawi, another large and meromictic lake in the African rift valley, Hamblin et al. (2003) showed that fluxes from the metalimnion and hypolimnion were dominated by upwelling caused by internal seiching, whereas vertical transport within the epilimnion was mainly due to turbulent mixing. $\mathrm{NH}_{4}^{+}$flux in Lake Kivu was within the lower range estimated for Lake Malawi (Table 6), and DIP and Si fluxes in Lake Kivu were lower than estimates for Lake Malawi. For Lake Tanganyika, much higher DIP and Si upward fluxes have been estimated, whereas dissolved $\mathrm{N}$ was suggested to be zeroed by the denitrification at the permanent oxic anoxic interface (Hecky et al. 1991). Interestingly, the $\mathrm{N}: \mathrm{P}$ ratio in the water column of Lake Kivu is $22: 1$, compared with $10: 1$ for the other two lakes. This higher ratio might indicate riverine inputs richer in nitrogen $(\mathrm{N}: \mathrm{P}=50: 1$ in rivers; Muvundja et al. in press) and might also explain the relatively lower abun- 
Table 6. Internal loading of nutrients in Lake Kivu compared with published values from Lakes Malawi and Tanganyika. Total upward nutrient fluxes are the fluxes calculated from 60 to $110 \mathrm{~m}$. Nutrient uptake rates by phytoplankton are estimated from literature values from primary production and nutrient ratios measured in the seston.

\begin{tabular}{|c|c|c|c|}
\hline & Lake Kivu & Lake Malawi & Lake Tanganyika \\
\hline Reference & This study & $\begin{array}{l}\text { Hamblin et al. 2003; } \\
\text { Bootsma et al. } 2003\end{array}$ & Hecky et al. 1991 \\
\hline $\mathrm{N}(\mathrm{mmol} \mathrm{m} 2 \mathrm{~d} 1)$ & 1.9 & 1.024 & 0 \\
\hline $\mathrm{DIP}\left(\mathrm{mmol} \mathrm{m}{ }^{2} \mathrm{~d}^{1}\right)$ & 0.087 & 0.193 .9 & 0.52 \\
\hline $\mathrm{Si}(\mathrm{mmol} \mathrm{m} 2 \mathrm{~d}$ 1) & 1.4 & 1.83 .2 & 18 \\
\hline Primary production $\left(\mathrm{mmol} \mathrm{C} \mathrm{m}^{2} \mathrm{~d}{ }^{1}\right)$ & 52 & 92167 & 4083 \\
\hline Seston $\mathrm{C}: \mathrm{N}: \mathrm{P}$ & $256: 26.8: 1$ & $223: 16.6: 1$ & $165: 16.7: 1$ \\
\hline $\mathrm{N}$ uptake $\left(\mathrm{mmol} \mathrm{m}{ }^{2} \mathrm{~d}{ }^{1}\right)$ & 5.4 & 6.812 & 4.08 .4 \\
\hline $\mathrm{P}$ uptake $\left(\begin{array}{lll}\mathrm{mmol} \mathrm{m}^{2} & \mathrm{~d} & 1\end{array}\right)$ & 0.20 & 0.410 .75 & 0.240 .50 \\
\hline
\end{tabular}

dance of nitrogen-fixing cyanobacteria in Lake Kivu (Sarmento et al. 2006).

Comparison of nutrient flux rates and phytoplankton uptake rates In Lake Kivu, recent primary production was $52 \mathrm{mmol} \mathrm{C} \mathrm{m}^{2} \mathrm{~d}^{1}$ (Sarmento et al. 2009), which was within the lower range of values for Lakes Malawi (Hamblin et al. 2003) and Tanganyika (Hecky and Fee 1981; Järvinen et al. 1999; Sarvala et al. 1999). Seston $\mathrm{C}: \mathrm{N}: \mathrm{P}$ ratios revealed (Table 6) that nutrient fluxes from the hypolimnion were approximately three times lower than uptake rates, a typical nutrient recycling rate within the epilimnion. However, this vertical transfer of nutrients to the epilimnion might also be inhibited at the oxycline by dark microbial production. Haberyan and Hecky (1987) suggested that a bacterial layer consumed DIP at the oxycline, short-circuiting the vertical transport of DIP and explaining the extremely P-deficient particulate matter of the mixed layer in Lake Kivu $(\mathrm{C}: \mathrm{N}: \mathrm{P}=530: 48: 1)$. A recent study confirmed that particulate matter $(\mathrm{C}: \mathrm{N}: \mathrm{P}=$ $256: 26.8: 1)$ was low in $\mathrm{P}$ however, to a lesser extent than previously measured (Sarmento et al. 2006).

Origin and fate of methane In Lake Kivu, understanding the methane cycle is important to assess why $\mathrm{CH}_{4}$ accumulates to such an extent in the deep water and whether accumulation and consumption of $\mathrm{CH}_{4}$ is in a steady state. Recently, Schmid et al. (2005) demonstrated that $\mathrm{CH}_{4}$ production in Lake Kivu exceeded its sink and estimated an average $\mathrm{CH}_{4}$ production of $23 \mathrm{mmol} \mathrm{m} 2 \mathrm{~d} \quad 1$ to explain the observed increase of the last $30 \mathrm{yr}$ (Fig. 2). Processes accountable for the oxidation of $\mathrm{CH}_{4}$ were anaerobic methane oxidation (AMO), which is intimately connected with the sulfur cycle (Treude et al. 2005), and oxidation with $\mathrm{O}_{2}$ at the oxycline. Analysis of the redox couple $\mathrm{SO}_{4}^{2}$ and $\mathrm{S}(-\mathrm{II})$ revealed that their gradients had exactly the opposite signs in the intermediate zone from 60 to $90 \mathrm{~m}$ (Fig. 4c), suggesting a direct reduction of sulfate to sulfide without intermediates. The total methane flux from
60 to $110 \mathrm{~m}$ was $9.4 \mathrm{mmol} \mathrm{m}{ }^{2} \mathrm{~d}^{1}$, corresponding to the average input to the epilimnion over several years. In comparison, the total flux of $\mathrm{SO}_{4}^{2} \quad\left(0.27 \mathrm{mmol} \mathrm{m} 2 \mathrm{~d} \quad{ }^{1}\right)$ was 35 times smaller, suggesting that only some $3 \%$ of the $\mathrm{CH}_{4}$ would be oxidized with $\mathrm{SO}_{4}^{2}$. However, in the oxic layer, aerobic $\mathrm{CH}_{4}$ oxidation could contribute significantly to the $\mathrm{CH}_{4}$ decrease because the total $\mathrm{O}_{2}$ flux between 0 and $60 \mathrm{~m}\left(13 \mathrm{mmol} \mathrm{m}^{2} \mathrm{~d}^{1}\right)$ was slightly higher than the $\mathrm{CH}_{4}$ flux. The rate for aerobic methane oxidation of $7.2 \mathrm{mmol} \mathrm{m} 2 \mathrm{~d}^{1}$ from a previous study (Jannasch 1975) is slightly lower than our estimates of $9.1 \mathrm{mmol} \mathrm{m} 2 \mathrm{~d} 1$. In addition, other processes might also play a role, such as exchange with the atmosphere, direct uptake by picoplankton, or both. Further experiments are in progress to better quantify $\mathrm{CH}_{4}$ oxidation rates and to identify whether other processes could be responsible for the $\mathrm{CH}_{4}$ sink.

This descriptive biogeochemical study points out subaquatic springs, nutrient turnover, calcite cycling, and methane oxidation as key processes influencing internal loading of permanently stratified Lake Kivu. The existence of a subaquatic spring entering the lake at $250 \mathrm{~m}$ and sustaining the major chemocline below could be demonstrated. This and other subaquatic springs drive vertical advection, which is the most important component determining upward nutrient fluxes. P, N, and Si upward fluxes in Lake Kivu are similar to those in Lake Tanganyika and Lake Malawi and constitute the major part of total nutrient inputs to the epilimnion. Another key process occurring at the oxycline is aerobic methane oxidation, which is mainly responsible for $\mathrm{CH}_{4}$ removal, whereas anaerobic methane oxidation can only consume a maximum of $3 \%$ of the methane transported out of the deep water. Finally, calcite precipitation is responsible for the depletion of $\mathrm{Ca}^{2+}, \mathrm{Sr}^{2+}$, and $\mathrm{Ba}^{2+}$ in surface waters and their enrichment in deep waters.

\section{Acknowledgments}

We are grateful to Fabrice Amisi Muvundja, Pascal Isumbisho, Boniface Kaningini, and Georges Alunga for water sampling; use 
of their laboratory for chemical analyses; and logistics in Congo. We thank Claudien Kabera and Antoine Ntamavukiro for logistics in Rwanda and Ruth Stierli for her advice and support for chemical analyses at Eawag. We especially thank Michael Schurter for water sampling and two unknown reviewers for critically reviewing our manuscript and Jean Pierre Descy for his support.

The project was supported by the Swiss National Science Foundation and the Swiss Agency for Development and Cooperation under grant 207021109710 (Nutrient cycling in Lake Kivu).

\section{References}

Bootsma, H. A., and R. E. Hecky. 1993. Conservation of the African Great Lakes: A limnological perspective. Conserv. Biol. 7: 644656.

, T. J. Johnson, H. J. Kling, And J. Mwita. 2003. Inputs, outputs, and internal cycling of silica in a large, tropical lake. J. Gt. Lakes Res. 29: 121138.

Botz, R., P. Stoffers, E. Faber, and K. Tietze. 1988. Isotope geochemistry of carbonate sediments from Lake Kivu (East Central Africa). Chem. Geol. 69: 299308.

Camacho, A., J. Erez, A. Chicote, M. Florín, M. M. Squires, C. LeHMANN, AND R. BACHOFEN. 2001. Microbial microstratifica tion, inorganic carbon photoassimilation and dark carbon fixation at the chemocline of the meromictic Lake Cadagno (Switzerland) and its relevance to the food web. Aquat. Sci. 63: 91106.

Degens, E. T., And G. Kulbicki. 1973. Hydrothermal origin of metals in some east African rift lakes. Mineral. Deposita 8: 388404.

, R. P. Von Herzen, H. K. Wong, W. G. Deuser, and H. W. Jannasch. 1972. Lake Kivu: Structure, chemistry and biology of an east African rift lake. Geol. Rundsch. 62: 245277.

DEW. 2004. Deutsche Einheitsverfahren zur Wasseruntersuchung (DEW). Wiley VCH.

DitTrich, M., AND M. ObST. 2004. Are picoplankton responsible for calcite precipitation in lakes? Ambio 33: 559564.

Haberyan, K. A., and R. E. Hecky. 1987. The late pleistocene and holocene stratigraphy and paleolimnology of Lakes Kivu and Tanganyika. Palaeogeogr. Palaeoclimatol. Palaeoecol. 61: 169197.

Hadas, O., And R. Pinkas. 2001. High chemoautotrophic pri mary production in Lake Kinneret, Israel: A neglected link in the carbon cycle of the lake. Limnol. Oceanogr. 46: 19681976.

Hamblin, P. F., H. A. Bootsma, and R. E. Hecky. 2003. Modeling nutrient upwelling in Lake Malawi/Nyasa. J. Gt. Lakes Res. 29: 3447.

Hecky, R. E., H. A. Bootsma, R. M. Mugidde, and F. W. B. BugENYI. 1996. Phosphorus pumps, nitrogen sinks, and silicon drains: Plumbing nutrients in the African Great Lakes, p. 205 233. In T. C. Johnson and E. O. Odada [eds.], The limnology, climatology and paleoclimatology of the East African lakes. Gordon and Breach.

, AND E. J. FEe. 1981. Primary production and rates of algal growth in Lake Tanganyika. Limnol. Oceanogr. 26: 532547.

, R. H. Spigel, and G. W. Coulter. 1991. The nutrient regime. Oxford Univ. Press.

Jannasch, H. W. 1975. Methane oxidation in Lake Kivu (Central Africa) Limnol. Oceanogr. 20: 860864
Jarvinen, M., K. Salonen, J. Sarvala, K. Vuorio, and A. VIRTANEN. 1999. The stoichiometry of particulate nutrients in Lake Tanganyika implications for nutrient limitation of phytoplankton. Hydrobiologia 407: 8188 .

Joye, S. B., T. L. Connell, L. G. Miller, R. S. Oremland, And R. S. Jellison. 1999. Oxidation of ammonia and methane in an alkaline, saline lake. Limnol. Oceanogr. 44: 178188.

Kilham, P., AND S. S. Kilham. 1990. Endless summer: Internal loading processes dominate nutrient cycling in tropical lakes. Freshw. Biol. 23: 379389.

Kim, G., H. S. YanG, And T. M. Church. 1999. Geochemistry of alkaline earth elements $(\mathrm{Mg}, \mathrm{Ca}, \mathrm{Sr}, \mathrm{Ba})$ in the surface sediments of the Yellow Sea. Chem. Geol. 153: 110.

MuvunduA, F., AND others. In press. Balancing nutrient inputs to Lake Kivu. J. Great Lakes Res.

Ojiambo, S. B., W. B. Lyons, K. A. Welch, R. J. Poreda, and K. H. Johannesson. 2003. Strontium isotopes and rare earth elements as tracers of groundwater lake water interactions, Lake Naivasha, Kenya. Appl. Geochem. 18: 17891805.

Plummer, L. N., And E. Busenberg. 1982. The solubilities of calcite, aragonite and vaterite in $\mathrm{CO}_{2} \mathrm{H}_{2} \mathrm{O}$ solutions between 0 and $90^{\circ} \mathrm{C}$, and an evaluation of the aqueous model for the system $\mathrm{CaCO}_{3} \mathrm{CO}_{2} \mathrm{H}_{2} \mathrm{O}$. Geochim. Cosmochim. Acta 46: 10111040.

Sarmento, H., M. Isumbisho, And J. P. Descy. 2006. Phytoplank ton ecology in Lake Kivu (eastern Africa). J. Plankton Res. 28: 815829 .

, S. Stenuite, F. Darchambeau, B. Leporce, and J. P. Descy. 2009. Phytoplankton ecology of Lake Kivu (eastern Africa): biomass, production and elemental ratio. Verh. Internat. Verein. Limnol. 30: 709713.

Sarvala, J. K., AND others. 1999. Trophic structure of Lake Tanganyika: Carbon flows in the pelagic food web. Hydro biologia 407: 149173 .

Schmid, M., M. Halbwachs, B. Wehrli, and A. Wuest. 2005. Weak mixing in Lake Kivu: New insights indicate increasing risk of uncontrolled gas eruption. Geochem. Geophys. Geosyst. 6: Q07009, doi:10.1029/2004GC000892.

, K. Tietze, M. Halbwachs, A. Lorke, D. McGinnis, and A. Wuest. 2004. How hazardous is the gas accumulation in Lake Kivu? Arguments for a risk assessment in light of the Nyiragongo Volcano eruption of 2002. Acta Vulcanol. 14/15: 115121.

Stumm, W., and J. J. Morgan. 1996. Aquatic chemistry: Chemical equilibria and rates in natural waters. Wiley Interscience.

TASSI, F., AND OTHERs. 2009. Water and gas chemistry at Lake Kivu (DRC): Geochemical evidence of vertical and horizontal heterogeneities in a multibasin structure. Geochem. Geophys. Geosyst. 10: Q02005, doi:10.1029/2008GC002191.

Tietze, K. 1978. Geophysical examination of Lake Kivu and its unusual methane deposit: Stratification, dynamics and gas content of the lake water. Ph.D. thesis. Christian Albrechts Univ. Kiel. [In German.]

Treude, T., J. Niggemann, J. Kallmeyer, P. Wintersteller, C. J. Schubert, A. Boetius, And B. B. Jørgensen. 2005. Anaerobic oxidation of methane and sulfate reduction along the Chilean continental margin. Geochim. Cosmochim. Acta 69: 27672779.

Associate editor: Robert E. Hecky

Received: 24 November 2008 Accepted: 06 May 2009 Amended: 03 June 2009 